\title{
INVESTIGACIÓN
}

\section{Effect of the essential volatile oils isolated from Thymbra capitata (L.) Cav. on olive and sunflower oils}

\author{
By M. G. Miguel ${ }^{1 *}$, A. C. Figueiredo ${ }^{2}$, M.M. Costa ${ }^{1}$, D. Martins ${ }^{1}$, J. G. Barroso ${ }^{2}$ and L. Pedro ${ }^{2}$
}

${ }^{1}$ Faculdade de Engenharia de Recursos Naturais, Universidade do Algarve, Campus de Gambelas, 8000-117 Faro, PORTUGAL

2Departamento de Biologia Vegetal, Faculdade de Ciencias de Lisboa, Bloco C2, Campo Grande, 1749-016 Lisbon, PORTUGAL

\section{RESUMEN}

Efecto de aceites volátiles esenciales aislados de Thymbra capitata (L.) Cav. En aceites de oliva y girasol.

Se analizaron, mediante GC y GC/MS, los componentes volátiles de aceites aislados de las distintas partes de la Thymbra capitata, recogida en diferentes etapas de desarrollo. Se evaluó la pitata, actividad antioxidante de estos aceites de la T. capitata, midiendo el índice de peróxidos, en aceites de oliva y girasol, almacenados $60^{\circ} \mathrm{C}$. Estos índices de peróxidos se compararon con los obtenidos cuando no se agregó ningún antioxidante (control) y cuando se utilizó BHT o carvacrol, en las mismas condiciones de almacenamiento. El mayor rendimiento en aceite se obtuvo de la parte aérea de $T$. capitata recogida durante la etapa de floración. E componente mayoritario de los aceites fue el carvacrol. También se encontraron, cantidades relativamente elevadas, de $p$-cimeno, $\gamma$-terpineno y $\beta$-cariofileno. El mejor antioxidante para el aceite de oliva resultó ser el BHT. En el aceite del girasol, la actividad antioxidante del BHT no fue tan evidente, mientras que el carvacrol y los aceites esenciales de $T$. capitata ricos en carvacrol mostraron una mayor actividad antioxidante.

PALABRAS-CLAVE: Aceite de girasol - Aceite de oliva - Aceites volátiles esenciales - Actividad antioxidante -- Carvacrol Thymbra capitata.

\section{SUMMARY}

Effect of the essential volatile oils isolated from Thymbra capitata (L.) Cav. on olive and sunflower oils.

The chemical composition of the volatile constituents of the oils isolated from different parts of Thymbra capitata collected at different developmental stages were analysed by GC and GCIMS. different developmental stages were analysed by GC and GC/MS The antioxidant ability of the oils isolated from $T$. capitata was evaluated determining the peroxide values, on olive and sunflowe oils, stored at $60^{\circ} \mathrm{C}$. These peroxide values were compared with those obtained when BHT, carvacrol and control (without adding antioxidants) were used and subjected to the same conditions. The best yield oil was obtained from the whole aerial part of $T$. capitata collected during the flowering phase. The major component of the oils was carvacrol. Relative high amounts of $p$-cymene, $\gamma$-terpinene and $\beta$-caryophyllene were also found. BHT revealed to be the best antioxidant when the olive oil was used. On sunflower oil, the antioxidant ability of BHT was not so evident, being the carvacrol-rich essential oils of $T$. capitata or carvacrol more important antioxidants.

KEY-WORDS: Antioxidant activity - Carvacrol - Essential volatile oils - Olive oil - Sunflower oil - Thymbra capitata.

\section{INTRODUCTION}

The oxidation of lipids in foodstuffs affects their quality due to the volatile compounds formed. The primary autoxidation products are hydroperoxides, odorless and tasteless, but their degradation products (odor-active carbonyl compounds, malonic dialdehyde, alkanes and alkenes) are very potent taste and flavour modifiers, rendering the product unacceptable for human consumption (Belitz and Grosch, 1999). Therefore, antioxidants have been used which scavange the peroxy and oxy free radicals formed during the propagation and the branching steps of autoxidation radical chain. Butylated hydroxyanisol $(\mathrm{BHA})$, butylated hydroxytoluene $(\mathrm{BHT})$, gallats and tert-butylhydroquinone (TBHQ) are synthetic antioxidants commonly used in food processing because they provide good protection for unsaturated fat and oils, and they have low cost and high stability (Tsimidou and Boskou, 1994; Özcan and Akgül, 1995; Dapkevicius et al., 1998; Belitz and Grosch, 1999). However, more recently, these substances have been questioned because they show some toxicity and carcinogenecity (Tsimidou and Boskou, 1994; Madsen and Bertelsen, 1995; Gámez-Meza et al., 1999; Özcan, 1999). Therefore, the demand for natural antioxidants has grown in order to render food products safer for mankind. Tocopherols, carotenoids and polyphenols (flavonoids, coumarins, phenolcarboxylic acids and anthocianins), ascorbic acid are examples of natural antioxidants isolated from different sources.

Among the various kinds of natural compounds, essential volatile oils are receiving attention as potential antioxidants, due to their importance in food preservation. Essential volatile oils from several aromatic plants are known to possess antioxidant activities (Lagouri et al., 1993; Tsimidou and Bouskou, 1994; Özcan and Akgül, 1995; Maestri et al., 1996; Baratta et al., 1998a; Baratta et al., 1998b; 
Dorman et al., 2000; Ruberto et al., 2000; Teissedre and Waterhouse, 2000).

In the present work, the chemical composition of the essential volatile oils isolated from the leaves of Thymbra capitata (L.) Cav. collected in Algarve, during the vegetative phase, and from different parts of the plant (leaves, flowers and whole aerial parts), during the flowering phase were examined by gas chromatography (GC) and gas chromatography coupled to mass spectrometry (GC/MS), after isolation by hydrodistillation. The essential volatile oils obtained from the whole aerial parts of $T$. capitata collected during the flowering phase were also tested in order to detect their antioxidant capability in different substrates (olive oil and sunflower oil).

\section{MATERIAL AND METHODS}

\subsection{Plant material}

The aerial parts of $T$. capitata were collected during the flowering phase (June 2000) at Algarve, and during the vegetative phase (February and April 2000). Voucher specimen has been deposited in the Herbarium of the Instituto Botânico da Faculdade de Ciências de Lisboa.

\subsection{Isolation procedure}

The essential volatile oils were isolated from fresh plant material $(30 \mathrm{~g})$ by hydrodistillation, for four hours, using a Clevenger-type apparatus.

\subsection{GC}

Gas chromatography analyses were performed using a Perkin Elmer 8700 gas chromatograph equipped with two FIDs, a data handling system and a vaporising injector port into which two columns of different polarities were installed: a DB-1 fused-silica column $(30 \mathrm{~m} \times 0.25 \mathrm{~mm}$ i. d., film thickness $0.25 \mu \mathrm{m} ; \mathrm{J} \& \mathrm{~W}$ Scientific Inc., Rancho Cordova, CA, USA) and a DB-17HT fused-silica column (30 m x $0.25 \mathrm{~mm}$ i. d., film thickness $0.15 \mu \mathrm{m} ; \mathrm{J} \& \mathrm{~W}$ Scientific Inc.). Oven temperature was programmed, $45-175^{\circ} \mathrm{C}$, at $3^{\circ} \mathrm{C} / \mathrm{min}$, subsequently at $15^{\circ} \mathrm{C}$ up to $300{ }^{\circ} \mathrm{C}$, and then held isothermal for $10 \mathrm{~min}$; injector and detector temperatures, $280{ }^{\circ} \mathrm{C}$ and $290{ }^{\circ} \mathrm{C}$, respectively; carrier gas, hydrogen, adjusted to a linear velocity of $30 \mathrm{~cm} / \mathrm{s}$. The samples were injected using split sampling technique, ratio 1:50. The percentage composition of the oils was computed by the normalisation method from the GC peak areas, calculated as mean values of two injections from each oil, without using correction factors.

\subsection{GC/MS}

Gas chromatography-mass spectrometry unit consisted of a Carlo Erba 6000 Vega gas chromatograph, equipped with a DB-1 fused-silica column $(30 \mathrm{~m} \times 0.25 \mathrm{~mm}$ i. d., film thickness $0.25 \mu \mathrm{m}$; J \& W Scientific Inc.), and interfaced with a Finnigam MAT 800 Ion Trap Detector (ITD; software version 4.1). Oven temperature was as above; transfer line temperature, $280{ }^{\circ} \mathrm{C}$; ion trap temperature, $220{ }^{\circ} \mathrm{C}$; carrier gas, helium, adjusted to a linear velocity of $30 \mathrm{~cm} / \mathrm{s}$; splitting ratio, 1:40; ionisation energy, $70 \mathrm{eV}$; ionisation current, $60 \mu \mathrm{A}$; scan range, 40-300 u; scan time, $1 \mathrm{~s}$. The identity of the components was assigned by comparison of their retention indices to $\mathrm{C}_{9}-\mathrm{C}_{17}$ n-alkanes, and mass spectra with corresponding data of components of reference oils.

\subsection{Sample preparation}

One hundred milligrams of the essential volatile oil isolated from the whole aerial part of $T$. capitata carvacrol or BHT were added to $100 \mathrm{~g}$ of the olive and the sunflower oils and the mixtures were stirred for 5 minutes, at room temperature. The samples were placed in closed beakers at $60^{\circ} \mathrm{C}$ in the dark. A control sample was prepared, under the same conditions, without adding any antioxidant.

\subsection{Antioxidant activity measurement}

The rate of oxidation was followed by periodic determination of peroxide values of the oils stored at $60{ }^{\circ} \mathrm{C}$. The oil $(5 \mathrm{~g})$ was added to a beaker containing $25 \mathrm{ml}$ of acetic acid/chloroform (3/2) and shaken. Saturated solution of potassium iodide $(1 \mathrm{ml})$ was then added and the beaker placed in a dark chamber for 5 minutes, after which $75 \mathrm{ml}$ distilled water was added. The liberated iodine was titrated with sodium thiosulfate solution $(0.01 \mathrm{M})$ in the presence of starch as an indicator (A.O.C.S., 1989).

Antioxidant activity was expressed by inhibitory ratio as follows, according to the formula used by Karamac and Amarowicz (1997):

$$
\text { Inhibitory ratio }=\frac{P V_{t}-P V_{c t}}{P V_{0}-P V_{c t}} \times 100 \%
$$

$\mathrm{PV}_{0}$-- peroxide value of the sample before heating.

$\mathrm{PV}_{\mathrm{t}}$-- peroxide value of sample with addition of antioxidant heated for $t$ days.

$\mathrm{PV}_{\mathrm{ct}}$-- peroxide value of control sample heated for t days.

\subsection{Statistical analysis}

The analytical values represent means of three replicates done at two different experiments. Data 
Table I

Oil yields and percentage composition of the essential oils of Thymbra capitata isolated from different aerial parts during the vegetative and the flowering phases

\begin{tabular}{|c|c|c|c|c|c|c|}
\hline \multirow{2}{*}{ Components } & \multirow[b]{2}{*}{$\mathrm{RI}^{\mathrm{a}}$} & \multicolumn{3}{|c|}{ June } & \multirow{2}{*}{$\begin{array}{l}\text { April } \\
\text { Leaf }\end{array}$} & \multirow{2}{*}{$\frac{\text { February }}{\text { Leaf }}$} \\
\hline & & $\begin{array}{l}\text { Aerial } \\
\text { part }\end{array}$ & Flower & Leaf & & \\
\hline Tricyclene & 921 & $t$ & $\mathrm{t}$ & $t$ & $t$ & $t$ \\
\hline$\alpha$-Thujene & 924 & 1.9 & 1.2 & 1.0 & 1.2 & 1.2 \\
\hline$\alpha$-Pinene & 930 & 0.8 & 0.4 & 1.0 & 0.6 & 0.5 \\
\hline Camphene & 938 & 0.2 & 0.1 & 0.2 & 0.2 & 0.1 \\
\hline Sabinene & 958 & t & $t$ & 0.1 & 0.1 & $t$ \\
\hline Octen-3-ol & 961 & 0.2 & 0.3 & 0.2 & 0.1 & 0.1 \\
\hline$\beta$-Pinene & 963 & 0.3 & $t$ & 0.4 & 0.4 & 0.2 \\
\hline Myrcene & 975 & 2.2 & 1.4 & 2.4 & 1.6 & 1.5 \\
\hline$\alpha$-Phellandrene & 995 & 0.4 & 0.2 & 0.3 & 0.2 & 0.2 \\
\hline$\delta$-3-Carene & 1000 & 0.2 & 0.1 & 0.1 & 0.1 & 0.1 \\
\hline$\alpha$-Terpinene & 1002 & 1.6 & 1.0 & 1.6 & 1.0 & 1.3 \\
\hline$p$-Cymene & 1003 & 6.2 & 3.2 & 9.4 & 8.3 & 4.3 \\
\hline$\beta$-Phellandrene & 1005 & 0.3 & 0.2 & 0.3 & 0.3 & 0.2 \\
\hline Limonene & 1009 & 0.4 & 0.5 & 0.4 & 0.3 & 0.2 \\
\hline cis- $\beta$-Ocimene & 1017 & $\mathrm{t}$ & $\mathrm{t}$ & $\mathrm{t}$ & 0.1 & $t$ \\
\hline Trans- $\beta$-Ocimene & 1027 & 0.3 & 0.1 & 0.1 & 0.1 & 0.1 \\
\hline$\gamma$-Terpinene & 1035 & 7.1 & 4.1 & 5.2 & 4.6 & 7.9 \\
\hline Trans-Sabinene hydrate & 1037 & 0.4 & 0.5 & 0.2 & 0.2 & 0.4 \\
\hline 2,5-Dimethylstyrene & 1059 & 0.1 & $t$ & $\mathrm{t}$ & 0.1 & $t$ \\
\hline Terpinolene & 1064 & 0.1 & 0.1 & 0.2 & 0.1 & 0.1 \\
\hline cis-Sabinene hydrate & 1066 & 0.2 & 0.1 & 0.1 & 0.1 & 0.1 \\
\hline Linalool & 1074 & 1.0 & 1.2 & 0.9 & 1.3 & 1.2 \\
\hline trans-p-2-menthen-1-ol & 1095 & $\mathrm{t}$ & 0.1 & 0.1 & 0.1 & $\mathrm{t}$ \\
\hline Borneol & 1134 & 0.5 & 0.3 & 0.6 & 0.7 & 0.3 \\
\hline Terpinen-4-ol & 1148 & 0.6 & 0.8 & 0.7 & 0.8 & 0.6 \\
\hline$\alpha$-Terpineol & 1159 & 0.3 & 0.2 & 0.1 & 0.2 & 0.1 \\
\hline Carvone & 1206 & 0.1 & $\mathrm{t}$ & 0.1 & $\mathrm{t}$ & $t$ \\
\hline Neral & 1206 & 0.2 & 0.1 & 0.2 & 0.1 & 0.1 \\
\hline Geranial & 1240 & 0.1 & $\mathrm{t}$ & 0.4 & 0.1 & $t$ \\
\hline Cumin alcohol & 1260 & 0.4 & $t$ & 0.3 & 0.1 & $t$ \\
\hline Thymol & 1275 & 0.4 & 0.3 & 0.7 & 0.1 & 0.3 \\
\hline Carvacrol & 1286 & 68.4 & 77.8 & 67.0 & 69.2 & 74.7 \\
\hline Eugenol & 1327 & $\mathrm{t}$ & 0.1 & $\mathrm{t}$ & $\mathrm{t}$ & 0.1 \\
\hline Carvacrol acetate & 1348 & $t$ & 0.1 & 0.1 & 0.3 & 0.2 \\
\hline$\beta$-Caryophyllene & 1414 & 2.3 & 2.4 & 0.9 & 1.8 & 2.7 \\
\hline Aromadendrene & 1428 & $\mathrm{t}$ & $t$ & $\mathrm{t}$ & 0.1 & $t$ \\
\hline$\alpha$-Humulene & 1447 & 0.2 & 0.1 & $t$ & 0.1 & 0.1 \\
\hline Bicyclogermacrene & 1487 & 0.3 & $\mathrm{t}$ & $\mathrm{t}$ & 0.1 & 0.2 \\
\hline$\beta$-Bisabolene & 1495 & 0.1 & 0.2 & 0.2 & 0.2 & $\mathrm{t}$ \\
\hline$\gamma$-Cadinene & 1496 & 0.2 & $\mathrm{t}$ & 0.1 & 0.1 & $\mathrm{t}$ \\
\hline$\delta$-Cadinene & 1505 & 0.4 & $\mathrm{t}$ & 0.2 & 0.1 & 0.1 \\
\hline Spathulenol & 1551 & 0.1 & 0.1 & $\mathrm{t}$ & 0.1 & 0.1 \\
\hline$\beta$-Caryophyllene oxide & 1561 & 0.4 & 0.2 & 0.3 & 0.5 & 0.3 \\
\hline Abietatriene & 2027 & $t$ & 0.1 & $t$ & 0.1 & 0.1 \\
\hline$\%$ Identification & & 98.9 & 97.6 & 96.1 & 95.9 & 99.7 \\
\hline \multicolumn{7}{|l|}{ Grouped components } \\
\hline Monoterpene hydrocarbons & & 22.1 & 12.6 & 22.7 & 19.3 & 17.9 \\
\hline Oxygen-containing monoterpenes & & 72.6 & 81.5 & 71.5 & 73.3 & 78.0 \\
\hline Sesquiterpene hydrocarbons & & 3.5 & 2.7 & 1.4 & 2.5 & 3.1 \\
\hline Oxygen-containing sesquiterpenes & & 0.5 & 0.3 & 0.3 & 0.6 & 0.4 \\
\hline Diterpenes & & $\mathrm{t}$ & 0.1 & $\mathrm{t}$ & 0.1 & 0.1 \\
\hline Phenylpropanoids & & $\mathrm{t}$ & 0.1 & $\mathrm{t}$ & $\mathrm{t}$ & 0.1 \\
\hline Others & & 0.2 & 0.3 & 0.2 & 0.1 & 0.1 \\
\hline Oil Yield (v/w) & & 3.2 & 2.5 & 2.0 & 2.2 & 1.2 \\
\hline
\end{tabular}

$\mathrm{a} \mathrm{RI}=$ Retention index, relative to $\mathrm{C} 9-\mathrm{C} 17 \mathrm{n}$-alkanes on the $\mathrm{DB}-1$ column . $\mathrm{t}=\operatorname{trace}(<0.05 \%)$ 
obtained were subjected to one-way analysis of variance and Tuckey's test analysis. Significance was declared at $\mathrm{p}<0.05$

\section{RESULTS}

The chemical composition of the essential volatile oils isolated from the aerial parts of Thymbra capitata collected at Nave do Barão (Algarve), during the vegetative and the flowering phases, and the yield oils, are depicted in Table I. The identified oil components, representing $95.9-99.7 \%$ of the total oils, are listed in order of their elution on a DB-1 column, after isolation by hydrodistillation. The highest oil yield $(3.2 \%, \mathrm{v} / \mathrm{w})$ was obtained from the whole aerial part of the plant sampled during the flowering phase, being the flowers the second more important material for obtaining a good oil yield $(2.5 \%)$. The lowest oil yield $(1.2 \%)$ was found in the leaves collected in April, while the remaining oil yields obtained from the leaves harvested in February and June were $2.0 \%$ and $2.2 \%$, respectively.

The oxygen-containing monoterpenes were the most representative group of compounds present in the essential volatile oils isolated from $T$. capitata. The percentages ranged from $71.5 \%$, in the leaf oils, in February, to $81.5 \%$, in the flower oils, in June. The monoterpene hydrocarbons constitute the second most important group of compounds (12.6-22.1\%). The sesquiterpene fraction was mainly constituted by the sesquiterpene hydrocarbons (1.4-3.5\%).

Carvacrol was the major compound, being the flower oils $(77.8 \%)$ the richest in this component whereas the leaf oils from the plants harvested in February only possessed $67.0 \%$. The isomer thymol was only found in small percentages $(0.1-0.7 \%)$ in the essential volatile oils of $T$. capitata.

The monoterpene hydrocarbons $p$-cymene and $\gamma$-terpinene were also present in considerable amounts in the essential volatile oils of $T$. capitata. The highest percentages of $p$-cymene were registered in the leaf oils $(9.4 \%)$ in February, contrasting to the flower oils, that only contained $3.2 \%$, in June. $\gamma$-Terpinene was also in lower levels in the flower oils $(4.1 \%)$, however in April the leaf oils contained $7.9 \%$. During the assay, it is noteworthy to refer the inverse correspondence between the amounts of carvacrol and its biogenetic precursor p-cymene. Concerning the amounts of $\gamma$-terpinene, such was not so evident, except for the flower oils that had the highest percentage of carvacrol, where the lowest amount of $\gamma$-terpinene was registered. $\gamma$-Caryophyllene was the most representative compound in the sesquiterpene fraction, whose concentrations ranged from $0.9 \%$ in the leaf oils, in February, to $2.7 \%$ in the leaf oils, in April.
Figures 1 and 2 depict the peroxide values of the essential volatile oils of $T$. capitata, carvacrol and BHT on olive oil and sunflower oil, respectively, at $60{ }^{\circ} \mathrm{C}$, over the time. The peroxide value of control was only significantly higher $\left(75.3 \mathrm{meq} \mathrm{O}_{2} / \mathrm{kg}\right.$ sample \pm 3.24 ) than the peroxide values observed for carvacrol and for the oil isolated from $T$. capitata after 31 days of experiment (Fig. 1). A significant high peroxide value $(197.5 \mathrm{meq} \mathrm{O} / \mathrm{kg}$ sample \pm 23.4 ) was observed for the control at the end of the experiment (40 days). It was evident that the peroxide value of $\mathrm{BHT}$ in olive oil was almost always significantly lower than the peroxide values of the remaining samples (Fig. 1). Such was confirmed through the inhibitory ratio (Table II) in which BHT presents the best significant inhibitory ratios, excepting at day 31 , when the value attained seems to be quite difficult to explain. Significant differences of the peroxide values as well as of the inhibitory ratios were not found between carvacrol and the essential volatile oils of $T$. capitata (Fig. 1 and Table II).

In the experiment carried out in the sunflower oil, the peroxide values did not differ significantly 15 days after the treatment (Fig. 2). Only after 31 days, the peroxide value found in the control was significantly superior (58.4 meq $\mathrm{O}_{2} / \mathrm{kg}$ sample \pm 1.55 ), reaching

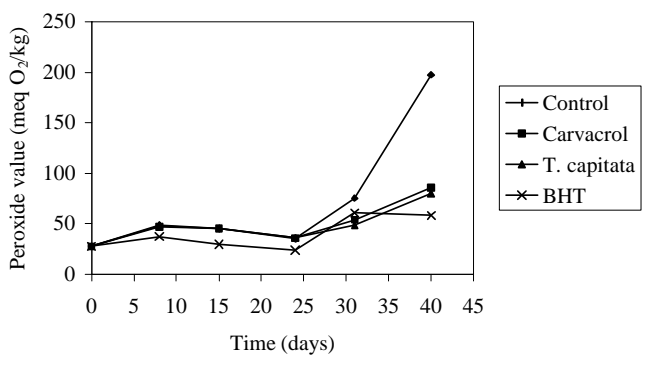

Figure 1

Peroxide value of olive oil at $60^{\circ} \mathrm{C}$.

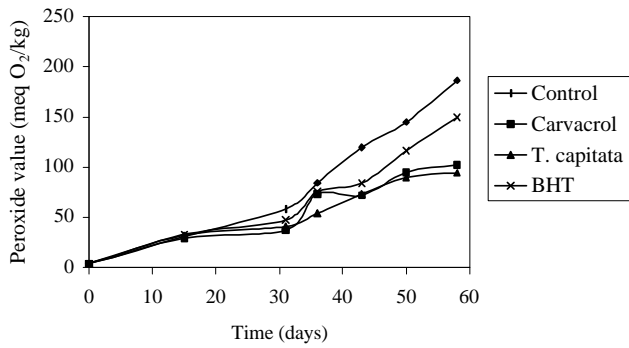

Figure 2

Peroxide value of sunflower oil at $60^{\circ} \mathrm{C}$. 
Table II

Inhibitory ratios of the essential volatile oils of $T$. capitata, carvacrol and BHT related to control, on olive oil, stored in the dark, at $60^{\circ} \mathrm{C}$

\begin{tabular}{|c|c|c|c|c|c|}
\hline \multicolumn{6}{|c|}{ Inhibitory ratio related to control sample (percentage) } \\
\hline \multicolumn{6}{|c|}{ Time (days) } \\
\hline & 8 & 15 & 24 & 31 & 40 \\
\hline \multicolumn{6}{|c|}{ Meants. e. } \\
\hline Carvacrol & $-9.4 \pm 24.2^{a}$ & $-1.9 \pm 6.7^{\mathrm{a}}$ & $3.7 \pm 3.5^{\mathrm{a}}$ & $44.8 \pm 4.8^{\mathrm{ab}}$ & $65.8 \pm 2.9^{\mathrm{a}}$ \\
\hline T. capitata & $-5.8 \pm 24.2^{\mathrm{a}}$ & $-4.2 \pm 6.7^{\mathrm{a}}$ & $-6.2 \pm 3.5^{a}$ & $55.6 \pm 4.8^{\mathrm{b}}$ & $69.2 \pm 2.9^{a}$ \\
\hline BHT & $76.5 \pm 24.2^{b}$ & $90.3 \pm 6.7^{b}$ & $100.0 \pm 3.5^{b}$ & $30.7 \pm 4.8^{a}$ & $99.4 \pm 2.9^{b}$ \\
\hline
\end{tabular}

s.e. $=$ standard error

Means with different superscript letters are significantly different $(p<0.05)$

Table III

Inhibitory ratios of the essential volatile oils of $T$. capitata, carvacrol and BHT related to control, on sunflower oil, stored in the dark, at $60^{\circ} \mathrm{C}$

\begin{tabular}{|c|c|c|c|c|c|c|}
\hline \multicolumn{7}{|c|}{ Inhibitory ratio related to control sample (percentage) } \\
\hline \multicolumn{7}{|c|}{ Time (days) } \\
\hline & 15 & 31 & 36 & 43 & 50 & 58 \\
\hline \multicolumn{7}{|c|}{ Mean \pm s. e. } \\
\hline Carvacrol & $8.5 \pm 7.6^{a}$ & $38.7 \pm 3.3^{b}$ & $13.7 \pm 2.3^{a}$ & $41.5 \pm 5.8^{a}$ & $35.5 \pm 8.3^{a}$ & $46.3 \pm 3.5^{\mathrm{b}}$ \\
\hline T. capitata & $1.7 \pm 7.6^{\mathrm{a}}$ & $32.6 \pm 3.3^{b}$ & $37.8 \pm 2.3^{b}$ & $40.3 \pm 5.8^{a}$ & $39.0 \pm 8.3^{a}$ & $50.4 \pm 3.5^{b}$ \\
\hline $\mathrm{BHT}$ & $-8.5 \pm 7.6^{a}$ & $19.9 \pm 3.3^{\mathrm{a}}$ & $10.7 \pm 2.3^{a}$ & $31.1 \pm 5.8^{\mathrm{a}}$ & $20.0 \pm 8.3^{a}$ & $20.3 \pm 3.5^{a}$ \\
\hline
\end{tabular}

s.e. $=$ standard error

Means with different superscript letters are significantly different $(p<0.05)$

the highest value ( 186.5 meq $\mathrm{O}_{2} / \mathrm{kg}$ sample \pm 6.6$)$ at the end of the experiment (58 days) (Fig. 2). Generally, differences of peroxide values between the essential volatile oils and carvacrol were not detected (Fig. 2). This similar effectiveness was confirmed by the inhibitory ratios found for those two samples that did not significantly differ (Table III).

The antioxidant activity of BHT on sunflower oil was not so evident when compared to the olive oil. On sunflower oil, the added carvacrol and the carvacrol rich-essential oils isolated from $T$. capitata revealed to be more effective as antioxidants than BHT, because the inhibitory ratios almost were significantly higher when compared to the inhibitory ratio of $\mathrm{BHT}$ (Table III).

\section{DISCUSSION}

The results of the oil yields agree with those reported by some authors (Falchi Delitala et al., 1983) obtained from plants of T. capitata harvested in Sardinia, during the flowering phase. Nevertheless, during the vegetative phase, these authors referred an increase of the oil yield from January to May. Despite our work not having the monthly oil yield, we obtained a better oil yield in February $(2.0 \%)$ than in April $(1.2 \%)$. For the same species, but collected at a different region of Algarve, the highest oil yield $(1.7 \%)$ obtained by Proença da Cunha and Roque
(1986), was inferior to our maximal yield (3.2\%), obtained from the whole aerial part of plants. The different geographic origin of the plants can explain such yield oil variability. The phenolic content of the essential oils was mainly constituted by carvacrol, identical to that reported by some authors (Salgueiro, 1994; Proenca da Cunha and Roque, 1986; Falchi Delitala et al., 1983; Kuštrak et al., 1990; Lagouri et al., 1993; Lawrence, 1999) for the same species but with different origins. In contrast, Ravid and Putievsky (1983) found in the oils of T. capitata sampled in Israel high levels of thymol (39.3\%), while carvacrol only attained $12.7 \%$ of the total oil.

Despite of the fact that flower oils possessed the highest concentration of carvacrol, the whole aerial part oils obtained from the plants during the flowering phase produced the highest oil yield. This fact established our choice when the essential oil from the aerial part of the plant was used for the antioxidant experiments.

The relative effectiveness of the added antioxidants carvacrol and carvacrol-rich oil isolated from $T$. capitata was not surprising, because it is known that phenolic derivatives have such ability. Such components form radicals which are stabilised by an aromatic ressonance system, not being able to abstract a $\mathrm{H}$-atom from an unsaturated fatty acid, and therefore incapable of initiating lipid peroxidation (Lagouri et al., 1993; Belitz and Grosch, 1999). The 
antioxidant activity similarities between carvacrol and the essential volatile oils isolated from $T$. capitata seems to reveal that carvacrol was the sole responsible for such activities, not existing other components in the volatile constituents of the plant that promote synergistic or antagonistic effects.

Some authors (Madsen and Bertelsen, 1995; Pokorny et al., 1998; Nguyen et al., 1999) refer that the rate of oxidation depends on the fatty acid composition of the lipid. For example, the more allyl groups present in the lipid the higher the oxidation rate. In addition, in the present work the lipids used as substrates, olive oil rich in oleic acid and sunflower oil rich in linoleic acid, were not purified, presenting, therefore, in their composition, natural antioxidants, such as tocopherols and other phenolic compounds in different concentrations. Also this kind of compounds is responsible for the different stability of the lipids. Although $\gamma$-tocopherol is a faster scavanger for peroxy radicals formed during autoxidation than $\alpha$-tocopherol, it generates an alkyl radical which, in contrast to the slow reacting chromanoxyl radical of $\gamma$-ocopherol, can start autoxidation of unsaturated fatty acids. Therefore, the peroxidation rate of an unsaturated fatty acid can increase with higher $\alpha$-tocopherol concentrations (Belitz and Grosch, 1999). All of these aspects can be responsible for the different effectiveness of the added antioxidants according to the substrate used. Sunflower oil is, therefore, difficult to stabilise because of both high linoleic acid and $\alpha$-tocopherol contents (average composition $63 \mathrm{~g} / 100 \mathrm{~g}$ and $56.4 \mathrm{mg} / 100 \mathrm{~g}$, respectively) (Belitz and Grosch, 1999). This different antioxidant efficiency is particularly evident for the synthetic antioxidant BHT. Such result can be understandable not only by the different concentrations of endogenous antioxidants that can influences the effectiveness of the antioxidant added, but also by due to the two tertiary butyl substituents of BHT. These groups can sterically hinder the reaction with radicals to a certain extent, which can become more significant for polyunsaturated acids, such as linoleic acid of sunflower oil. Such sterical restriction does not exist in carvacrol.

The results obtained in this work agree with those previously reported by some authors (Bauman et al., 1999), which refer that BHA, another synthetic antioxidant generally used, was more efficient as antioxidant on beef tallow than on groundnut oil or on sunflower oil.

\section{CONCLUSIONS}

The major component of the essential volatile oils of $T$. capitata, independently of the developmental stage or of the plant part used, collected at Algarve, was carvacrol. The results indicated that the essential volatile oils of the whole aerial part of the plant and carvacrol, both used in $0.1 \%(\mathrm{w} / \mathrm{w})$, were more effective as antioxidants on sunflower oil than the synthetic BHT, used in the same concentration. In olive oil, BHT was a better antioxidant than carvacrol or the T. capitata oil, used in the same concentrations $(0.1 \%, w / w)$. Generally, similar antioxidant activities were found for carvacrol or for the essential volatile oils used, indicating an absence of synergistic or antagonistic effect promoted by the remaining components present in the volatile essential oils isolated from $T$. capitata.

The authors would like to acknowledge the financial support from the Centro de Desenvolvimento de Ciências e Técnicas de Produção Vegetal (CDCTPV) and the Centro de Biotecnologia Vegetal, Instituto de Biotecnologia e Química Fina (IBQF).

\section{REFERENCES}

A.O.C.S. (1989). Official methods and recommended practices. Vol. I, $4^{\text {th }}$ edn., $2^{\text {nd }}$ print (including 1990 and 1992 additions and revisions). American Oil Chemists Society, Champaign, ILL.

Baratta, M. T. Dorman, H. J. D., Deans, S. G., Figueiredo, A. C., Barroso, J. G. and Ruberto, G. (1998a). Antimicrobial and antioxidant properties of some commercial essential oils. Flavour Fragr. J., 13, 235-244.

Baratta, M. T., Dorman, H. J. D., Deans, Biondi, D. M. and Ruberto, G. (1998b). Chemical composition, antimicrobial and antioxidative activity of laurel, sage, rosemary, oregano and coriander essential oils. $J$. Essent. Oil Res., 10, 618-627.

Bauman, D., Hadolin, M., Rizner-Hraš and Knez Z. (1999) Supercritical fluid extraction of rosemary and sage antioxidants. Acta Alimentaria, 28, 15-28.

Belitz, H.-D. and Grosch, W. (1999). Food Chemistry, $2^{\text {nd }}$ Ed., Springer-Verlag (Berlin, Heidelberg).

Dapkevicius, A Venskutonis, $R$ van Beek, T. A and Linssen, J. P. H. (1998). Antioxidant activity of extracts obtained by different isolation procedures from some aromatic herbs grown in Lithuania. J. Sci. Food Agric., 77, 140-146.

Falchi Delitala, L., Solinas, V. and Gessa, C. (1983) Variazioni stagionali quantitative e qualitative di olio essenziale e dei suoi fenoli in Thymus capitatus Hofmgg. et Lk. ed in Thymus herba-barona Loisel.. Fitoterapia, 59, 87-96.

Dorman, H. J. D., Figueiredo, A. C., Barroso, J. G. and Deans, S. G. (2000). In vitro evaluation of antioxidant activity of essential oils and their components. Flavour Fragr. J., 15, 12-16.

Gámez-Meza, N., Noriega-Rodríguez, J. A., MedinaJuárez, L. A., Ortega-García, J., Cázarez-Casanova, R. and Angulo-Guerrero, O. (1999). Antioxidant activity in soybean oil of extracts from Thompson grape bagasse. J. Am. Oil Chem. Soc., 76, 1445-1447.

Karamac, M. and Amarowicz, R. (1997). Antioxidant activity of BHA, BHT and TBHQ examined with Miller's test. Grasas y Aceites, 48, 83-86.

Kuštrak, D., Martinis, Z., Kuftinec, J. and Blazevic, N. (1990). Composition of the essential oils of some Thymus and Thymbra species. Flavour Fragr. J., 5, 227-231. 
Lagouri, V., Blekas, G., Tsimidou, M., Kokkini, S. and Boskou, D. (1993). Composition and antioxidant activity of essential oils from Oregano plants grown wild in Greece. Z. Lebensm. Unters. Forsch., 197, 20-23.

Lawrence, B. M. (1999) Progress in Essential Oils. Perfumer \& Flavorist, 24, 35-47.

Madsen, H. L. and Bertelsen, G. (1995). Spices and antioxidants. Trends in Food Science and Technology, 6, 271-277.

Maestri, D. M., Zygadlo, J. A., Lamarque, A. L., Labuckas, D. O. and Guzmán, C. A. (1996). Effect of some essential oils on oxidative stability of peanut oil. Grasas essential oils on oxidative
y Aceites, 47, 397-400.

Özcan, M. (1999). Antioxidant activity of rosemary (Rosmarinus officinalis L.) extracts on natural olive and sesame oils. Grasas Y Aceites, 50, 355-358.

Özcan, M., and Akgül, A. (1995). Antioxidant activity of extracts and essential oils from Turkish spices on sunflower oil. Acta Alimentaria, 24, 81-90.

Pokorny, J., Réblová, Z., Trojáková, L., Nguyen, H. T. T., Korczak, J. and Janitz, W. (1998). Antioxidant activities of spices and herbs in rapeseed oil in Proceedings of the World Conference on Oilseed and Edible Oils Processing, p. 265-269. S. S. Koseoglu, K. C. Rhee, R. F. Wilson (Ed.) AOCS Press.
Nguyen, H. T. T., Pokorny, J. and Korczak, J. (1999). Antioxidant activities of rosemary and sage extracts in rapeseed and sunflower oils. Czech. J. Food Sci., 17, 121-126.

Proença da Cunha, A. and Roque, O. R. (1986). Contribuição para o estudo analítico do óleo essencial de Thymus capitatus. Bol. Fac. Farm., 10, 31-41.

Ruberto, G., Baratta, M. T., Deans, S. G. and Dorman, H. J. D. (2000). Antioxidant and antimicrobial activity of Foeniculum vulgare and Crithmum maririmum essential oils. Planta Medica, 66, 687-693.

Salgueiro, L. R. (1994). Os tomilhos Portugueses e os seus óleos essenciais. Doctoral Thesis, Vol. 1. Faculty of Pharmacy, University of Coimbra, Portugal.

Teissedre, P. L. and Waterhouse, A. L. (2000). Inhibition of oxidation of human low-density lipoproteins by phenolic substances in different essential oils varieties. J. Agric. Food Chem. 48, 3801-3805.

Tsimidou, M. and Boskou, D. (1994). Antioxidant activity of essential oils from the plants of the Lamiaceae family essential oils from the plants of the Lamiaceae family
in Spices, Herbs and Edible Fungi, p. 273-284. G. Charalambous (Ed.). Elsevier, . Science B. V.

Recibido: Diciembre 2001 Aceptado: Diciembre 2002 